\title{
Maatilakytkentäisten yritysten innovatiiviset liiketoimintakonseptit
}

\author{
Päivi Kujala ${ }^{1)}$, Matti Ylätalo ${ }^{1)}$, Pekka Lehtonen ${ }^{1)}$ \\ ${ }^{1)}$ Helsingin yliopisto, taloustieteen laitos, PL 27, 00014 Helsingin yliopisto \\ paivi.kujala@helsinki.fi, matti.ylatalo@helsinki.fi, pekka.lehtonen@helsinki.fi
}

\section{TIIVISTELMÄ}

Tutkimuksen tavoitteena oli tutkia maatilakytkentäisten yritysten kehittämistä ja kasvua erityisesti innovatiivisten liiketoimintakonseptien näkökulmasta. Tämä tavoite jaettiin seuraaviin osatavoitteisiin.

1. millä tavalla innovatiivisuus vaikuttaa maatilakytkentäisten yritysten kehittämiseen ja taloudelliseen kasvuun

2. millainen on menestyvän maatilakytkentäisen yrityksen liiketoimintakonsepti

3. mikä on yrittäjäjohtajuuden merkitys innovaatioiden hyödyntämisessä

4. miten innovaatioympäristö tukee yritystoiminnan syntymistä ja kasvua maaseudulla.

Tutkimuksen kohderyhmänä oli Etelä-Pohjanmaan TE-keskuksen alueella vuosina 1995 1999 maaseutuelinkeinolain mukaista pienyritystoiminnan rahoitustukea saaneet yritykset. Tutkimus toteutettiin strukturoituna lomakekyselynä osoitetietojen luovutusluvan tutkimus- ja neuvontatarkoitukseen antaneelle 351 yrittäjälle. Kyselylomakkeella tiedusteltiin $\mathrm{mm}$. liikevaihdon, työllistävyyden, koulutus- ja tuotekehitysmenojen kehitystä vuoteen 2004 mennessä, yritysten verkostoitumista, omia näkemyksiä yritystoiminnan innovatiivisuudesta sekä tulevaisuuden kehittämissuunnista. Lomakekyselyn lisäksi tutkimuksessa tehtiin kuuden pienyritystoiminnan asiantuntijan ja kuuden yrittäjän haastattelut puolistrukturoidulla teemahaastattelulla.

Kyselytutkimus lähetettiin helmikuussa 2005. Vastauksia saatiin yhteensä 199 yrittäjältä, joten vastausprosentiksi saatiin korkeahko osuus, $57 \%$. Kyselytutkimukseen vastanneista yrittäjistä $85 \%$ oli miehiä ja $14 \%$ naisia. Yrittäjien keski-ikä oli 49 vuotta. Yritykset työllistivät keskimäärin 1,52 henkilötyövuotta.

Kyselyaineiston analysointi tehtiin SPSS- tilasto-ohjelmalla. Kyselytutkimuksen analysointia varten muodostettiin kolme vertailuryhmää perustuen yrittäjän omaan näkemykseen yritystoiminnan kehittämisen luonteesta. Ryhmät nimettiin sisältönsä mukaisesti: tuoteinnovaatio-ryhmä, muu innovaatio-ryhmä ja perinteinen konsepti-ryhmä. Lisäksi haastatteluosuudessa yrittäjät jaettiin vertailuryhmiin yrittäjäjohtajuuden mukaan. Johtajat luokiteltiin joko sarjayrittäjyyttä tai portfolioyrittäjyyttä harjoittaviksi yrittäjiksi. Tutkimusmenetelmänä oli siis yhdistetty kysely- ja haastattelututkimus.

Tutkimuksen kyselylomakkeen tulosten perusteella vertailuryhmien välillä oli tilastollisesti merkitsevä ero markkina-alueiden, vuoden 2004 ja ennustevuosien liikevaihdon, velkamäärän, tuotekehitysmenojen, patentin hakemisen ja oman työn osuudessa yritystoiminnassa.

Haastatteluihin perustuen voitiin todeta, että maatilakytkentäisten yritysten liiketoimintakonseptien kivijalkana olivat luovat, rohkeat ja samalla rauhalliset, eteenpäin katsovat yrittäjäjohtajat. Sarjayrittäjien oman alan ydinosaaminen oli muodostunut useiden yritysten johtamiskokemuksen kautta. Portfolioyrittäjien ydinosaaminen oli syntynyt tuotekehityksen ja kokeilujen kautta. Portfolioyrittäjät pystyivät hyödyntämään maatilan omaisuuseriä muun yritystoiminnan strategisina omaisuuserinä (RBV). Saman pystyivät tekemään myös haastatellut sarjayrittäjät.

Tutkimus vahvistaa sen näkemyksen, että innovaatioiden syntyminen maatilakytkentäisissä yrityksissä on pitkälti yrittäjien varassa. Innovaatioiden syntymisessä tärkeintä on ollut yrittäjän omat ideat, tieto, osaaminen ja rohkeus idean kehittelyssä innovaatioksi. Innovaatioympäristön osalta tutkimuksessa nousee esille tarve tukea yrityksen innovatiivista ja kasvuhakuista toimintaa liiketoimintaosaamiseen ja verkostoitumiseen liittyvillä instrumenteilla. Innovaatioympäristölle asetetaan yleisesti haasteita ja siihen sijoitetaan verraten paljon yhteiskunnan resursseja. Kasvun aikaansaamiseksi maatilakytkentäisissä yrityksissä innovaatioympäristön resurssien käytön tehostamiseen ja kohdentamiseen on selkeä tarve tämän tutkimuksen tulosten valossa.

Asiasanat: maatilakytkentäinen yritys, innovatiivisuus, liiketoimintakonsepti, innovaatioympäristö 


\title{
Maatilakytkentäisten yritysten innovatiiviset liiketoimintakonseptit
}

\author{
Päivi Kujala ${ }^{1)}$, Matti Ylätalo ${ }^{1)}$, Pekka Lehtonen ${ }^{1)}$ \\ ${ }^{1)}$ Helsingin yliopisto, taloustieteen laitos, PL 27, 00014 Helsingin yliopisto \\ paivi.kujala@helsinki.fi, matti.ylatalo@helsinki.fi, pekka.lehtonen@helsinki.fi
}

\section{Johdanto}

Innovaatiot ovat tärkein tuotannon, tuottavuuden, taloudellisen kasvun ja hyvinvoinnin lähde (Tekes 2003, s. 6). Innovaatiot ovat keskeisiä uuden yritystoiminnan käynnistämisessä ja myös olemassa olevien yritysten kasvussa ja kehittämisessä. Yleisesti vallalla on ollut käsitys, että merkittävät innovaatiot syntyvät kaupungeissa. Maaseutuyrittäjyyteen mielletään luonnonläheisyys, harmonia ja alkutuotantovaltaisuus samalla, kun maaseutua pidetään usein vanhanaikaisena ja perinteitä säilyttävänä toimintaympäristönä.

Maaseutu tarvitsee taloudellisesti menestyviä ja kilpailukykyisiä yrityksiä säilyäkseen elinvoimaisena. Maaseudun vahvuutena innovaatioiden tuottamisessa ovat monialaiset, rohkeat ja luovat maaseudun osaajat, maaseudun vihreys ja rauha sekä mahdollisuus integroitua ympäröivään alati muuttuvaan maailmaan nopeiden tietoliikenneyhteyksien välityksellä.

Maa- ja metsätalousministeriön tietopalvelukeskuksen tekemän maatalouden rakennetutkimuksen (Tike 2004) mukaan vuonna 2003 Suomessa oli 23551 monialaista maatilaa. Monialaisten tilojen osuus maatilojen kokonaismäärästä oli $32 \%$. Prosentuaalisesti eniten monialaisia maatiloja oli Uudellamaalla, 43 \% maatilojen kokonaismäärästä. Lukumääräisesti eniten monialaisia maatiloja oli Etelä-Pohjanmaalla, 2344 maatilaa, 28 \% maatilojen kokonaismäärästä. Tässä tutkimuksessa tarkasteltiin monialaisten maatilojen muuta yritystoimintaa. Näkökulmana ovat yritysten innovatiiviset liiketoimintakonseptit.

Tutkimuksen teoriapohjana on endogeeninen kasvuteoria. Endogeenisen kasvuteorian painottaa yritykseen sisältyvän inhimillisen pääoman ja ideoiden merkitystä taloudellisen kasvun tekijöinä. Innovaatioperusteisia kasvumalleja ovat kehittäneet mm. Romer sekä Aghion ja Howitt. Romerin $(1990,1994)$ mallin mukaan innovaatiopotentiaali sisältyy työpanokseen, mikä on ennalta tiedossa. Näin ollen innovaatiokustannukset ovat tietyllä hetkellä vakio. Markkinoille tulevat uudet tuotteet eivät kokonaan syrjäytä vanhempien tuotteiden kysyntää, sillä uusiin tuotteisiin sisältyy aina vain jotain uusia piirteitä. Aghionin ja Howitin (1992) luovan tuhon kasvumallissa innovaatioiden syntyyn liittyy aina tiettyä epävarmuutta eli ei-vakioisuutta ja uusi innovaatio syrjäyttää aina vanhan innovaation (nk.Schumpeterilainen luova tuho).

Tutkimuksessa haettiin vastausta neljään kysymykseen:

1. millä tavalla innovatiivisuus vaikuttaa maatilakytkentäisten yritysten kehittämiseen ja taloudelliseen kasvuun

2. millainen on menestyvän maatilakytkentäisen yrityksen liiketoimintakonsepti

3. mikä on yrittäjäjohtajuuden merkitys innovaatioiden hyödyntämisessä

4. miten innovaatioympäristö tukee yritystoiminnan syntymistä ja kasvua maaseudulla.

\section{Aineisto ja menetelmät}

Tutkimuksen kohderyhmänä olivat Etelä-Pohjanmaan TE-keskuksen alueella vuosina 1995 - 1999 pienyritystoiminnan rahoitusavustusta saaneet maatilakytkentäiset yritykset. Tutkimukseen otettiin mukaan kaikki rahoitustukea saaneet osoitteen luovutusluvan tutkimus- ja neuvontatarkoitukseen antaneet yrittäjät. Maaseutuelinkeinorekisterin osoitetietojen luovutuslupa hankittiin maa- ja metsätalousministeriöstä ja osoitetietojen ajo tehtiin TE-keskuksessa. Osoitetietojen luovutusluvan antaneita yrittäjiä oli 351.

Tutkimuksen kvantitatiivinen aineisto kerättiin strukturoidulla lomakekyselyllä rahoitustukea saaneilta yrittäjiltä. Kyselylomakkeella kysyttiin yritystoimintaan liittyviä tietoja kolmen eri vuositiedon mukaisesti, vuosi ennen rahoitustuen saamista, ensimmäinen rahoitustukivuosi ja vuosi 2004. Seurantajakso vaihteli yrityksittäin 6-8 vuoden välillä. Tutkimuksen kvalitatiivisen aineiston muodosti 
kuuden maaseudun pienyritystoiminnan asiantuntijan sekä kuuden innovatiivisen liiketoimintakonseptin omaavan maatilakytkentäisen yrittäjän haastattelut.

Kyselyaineiston analysointi tehtiin SPSS- tilasto-ohjelmalla. Kyselytutkimuksen analysointia varten muodostettiin kolme vertailuryhmää perustuen yrittäjän omaan näkemykseen yritystoiminnan kehittämisen luonteesta. Ryhmät nimettiin sisältönsä mukaisesti: tuoteinnovaatio-ryhmä, muu innovaatio-ryhmä ja perinteinen konsepti-ryhmä. Tuoteinnovaatio-ryhmän muodostivat yrittäjät, jotka olivat tuottaneet uuden tuotteen uusille markkinoille tai uuden tuotteen vanhoille markkinoille. Мuи innovaatio-ryhmän muodostivat yrittäjät, joiden näkemysten mukaan oma yritystoiminta oli innovatiivista jonkin seuraavan asian perusteella: vanha tuote uusille markkinoille, vanha tuote vanhoille markkinoille uudella markkinointitavalla, muualla toteutetun idean ottaminen oman yrityksen käyttöön, kustannussäästö teknologisella innovaatiolla, markkinointi-innovaatio, asiakasrahoituksen kehittäminen tai palveluinnovaatio. Perinteinen konsepti-ryhmän muodostivat yrittäjät, jotka ilmoittivat toimineensa samalla tutulla liiketoimintatavalla.

Tutkimuksessa haastatellut yrittäjät jaettiin yrittäjäjohtajuuden mukaan kahteen ryhmään, sarjayrittäjiin ja portfolioyrittäjiin. Sarjayrittäjiin luettiin ne yrittäjät, joilla oli johtamiskokemusta useamman kuin yhden yrityksen tai organisaation johtamisesta maatilatalouden lisäksi. Sarjayrittäjät edustivat kyselytutkimuksen mukaista muu innovaatio-ryhmää. Portfolioyrittäjiin liitettiin ne yrittäjät, jotka harjoittivat yhtä yritystoimintaa maatilatalouden lisäksi. Portfolioyrittäjät edustivat kyselytutkimuksen mukaista tuoteinnovaatio-ryhmää. Liiketoimintakonsepti muodostettiin tutkimuksessa Hamelin (2001) mallin mukaisesti. Liiketoimintakonsepti koostuu ydinstrategiasta, strategisista resursseista, asiakaspinnasta ja arvoverkostosta (Lehtonen, kotisivu kohta Liiketoimintaosaaminen ja Tapayrittäjyys).

Asiantuntijoiden haastattelujen tuloksia käytettiin lähinnä tutkimusongelman erityiskysymysten taustoittamiseksi.

\section{Tulokset ja tulosten tarkastelu}

Tuoteinnovaatio- ja тии innovaatio-ryhmän yritykset olivat olleet keskimääräisen liikevaihdon perusteella tarkasteltuna hieman suurempia ensimmäisenä rahoitustukivuotena kuin perinteinen konseptiryhmän yritykset (Taulukko 1). Kaikkien yritysryhmien keskimääräinen liikevaihto oli kehittynyt positiivisesti seurantajakson aikana, mutta samalla ero ryhmien välillä oli suurentunut. Tuoteinnovaatioryhmän keskimääräinen liikevaihto vuonna 2004 oli selvästi suurempi kuin muи innovaatio- ja perinteinen konsepti-ryhmien yritysten. Erityisesti on huomattava, että vaikka tuoteinnovaatioryhmän yritykset keskimäärin olivat pienempiä aloitusvuonna kuin muu innovaatioryhmä niin niiden liikevaihto kolminkertaistui tarkasteluajanjaksolla verrattuna тии innovaatioryhmän liikevaihdon kaksinkertaistumiseen. Perinteisten liikekonseptien yritysten liikevaihto nousi lähes kaksinkertaiseksi. Yritysryhmien arviot tulevasta liikevaihdon kehityksestä poikkesivat myös tilastollisesti merkitsevästi toisistaan, innovatiiviset ryhmät arvioivat tulevaisuuden myynnin kasvun suhteellisesti suuremmaksi kuin perinteinen konsepti-ryhmän yritykset. Tästä voidaan päätellä, että kasvun kannalta tuoteinnovaatiot ovat tärkeämmässä asemassa kuin esimerkiksi prosessi-innovaatiot.

Taulukko 1. Yritysten liikevaihdon kehitys ja liikevaihtoennusteet.

\begin{tabular}{|c|c|c|c|c|c|c|c|}
\hline & \multicolumn{2}{|c|}{$\begin{array}{c}\text { Tuote- } \\
\text { innovaatio } \\
(\mathrm{n}=42)\end{array}$} & \multicolumn{2}{|c|}{ Muu innovaatio } & Perinteiner & konsepti & \multirow[t]{2}{*}{ p-arvo } \\
\hline & Keskiarvo $€$ & Mediaani $€$ & Keskiarvo $€$ & Mediaani $€$ & Keskiarvo $€$ & Mediaani $€$ & \\
\hline Vuosi ennen & 66600 & 8000 & 69500 & 7000 & 33599 & 1173 & 0,170 \\
\hline 1. rahoitustukivuosi & 87052 & 13000 & 98739 & 20000 & 44575 & 10000 & 0,346 \\
\hline Vuonna 2004 & 188904 & 34000 & 140731 & 29134 & 63847 & 12800 & 0,045 \\
\hline Vuosi 2005 & 213391 & 37500 & 163200 & 52500 & 64856 & 20000 & 0,034 \\
\hline
\end{tabular}

Keskimääräinen lainamäärä oli innovatiivisilla yritysryhmillä huomattavasti suurempi kuin perinteinen konsepti-ryhmällä (Taulukko 2). Tuoteinnovaatio- ja mии innovaatio-ryhmien keskimääräinen lainamäärä oli kasvanut tutkimuksen seurantajakson aikana, kun taas perinteinen konsepti- 
ryhmän yritysten keskimääräinen lainamäärä oli pienentynyt ensimmäisen rahoitustukivuoden jälkeen. Kasvu vaati siis kohdeyrityksiltä tulorahoituksen lisäksi velkarahoituksen kasvua. Perinteinen konsepti-ryhmän yritykset olivat siten vakavaraisimpia suhteellisen velkaantuneisuuden perusteella arvioituna. Suhteellinen velkaantuneisuus oli silti tuoteinnovaatio- ја тии innovaatio-ryhmien yrityksillä erittäin kohtuullinen ja hallittavissa oleva.

Taulukko 2. Pitkäaikaisen velkamäärän kehittyminen seurantajakson aikana.

\begin{tabular}{|c|c|c|c|c|c|c|c|}
\hline & \multicolumn{2}{|c|}{$\begin{array}{c}\text { Tuote- } \\
\text { innovaatio } \\
(\mathrm{n}=48)\end{array}$} & Muu inı & iovaatio & Perinteine & n konsepti & \multirow[t]{2}{*}{ p-arvo } \\
\hline & Keskiarvo $€$ & Mediaani $€$ & Keskiarvo $€$ & Mediaani $€$ & Keskiarvo $€$ & Mediaani $€$ & \\
\hline Vuosi ennen & 24490 & 0 & 35658 & 11770 & 3468 & 0 & 0,000 \\
\hline 1. rahoitustukivuosi & 34063 & 10000 & 40880 & 20000 & 14466 & 9000 & 0,029 \\
\hline Vuonna 2004 & 40512 & 4500 & 49464 & 11000 & 9085 & 0 & 0,030 \\
\hline
\end{tabular}

Tuotekehitysmenojen osalta yritysryhmät poikkesivat toisistaan tilastollisesti merkitsevästi koko seurantajakson ajan (Kruskal-Wallis -testin p-arvo 0,001 vuonna 2004). Tuoteinnovaatioryhmän yritykset olivat käyttäneet tuotekehitykseen vuonna 2004 keskimäärin 6127 euroa, тии innovaatio-ryhmän yritykset 1048 euroa ja perinteinen konsepti-ryhmän yritykset 668 euroa. Tuotekehitykseen käytetty keskimääräinen rahamäärä oli noussut tuoteinnovaatio- ja тии innovaatio-ryhmän yrityksillä koko seurantajakson ajan. Tuotekehitysmenojen mediaani oli тии innovaatio- ja perinteinen konsepti-ryhmän yrityksillä nolla. Tuotekehitysmenojen suhteellinen osuus liikevaihdosta oli tuoteinnovaatio-ryhmällä 3,2 \%, тии innovaatio-ryhmällä $0,7 \%$ ja perinteinen konsepti-ryhmällä $1,1 \%$. Tutkimus- ja kehitysmenot olivat suomalaisissa yrityksissä keskimäärin 3,5 \% vuonna 2004 (Hautamäki ja Kuusi 2005, s. 6). Mainittakoon, että innovatiivisen yrityksen T\&K- kulujen rajana pidetään 4 \% /liike-vaihdosta. Tässä tutkimuksessa kohdeyritykset olivat pieniä alle 2 henkilöä keskimäärin työllistäviä yrityksiä. Yrittäjän itsensä tekemä T\&K- panostus ei välttämättä kokonaan sisälly tuloslaskelman palkkakuluihin ja sitä kautta jaoteltavaksi operatiivisiin ja kehittämispalkkoihin. Yrittäjävoittoon sisältyvä yrittäjän tekemä $T \& K-$ panostus ei näin ollen näy näissä luvuissa.

Koulutusmenot eivät poikenneet ryhmien välillä tilastollisesti merkitsevästi. Ensimmäisenä rahoitustukivuotena yritysryhmät käyttivät koulutukseen rahaa lähes saman verran (156 euroa). Vuonna 2004 koulutukseen käytettiin rahaa siten, että tuoteinnovaatio-ryhmä käytti 712 euroa, тии іпnоvaatio-ryhmä 240 euroa ja perinteinen konsepti-ryhmä 136 euroa keskimäärin. Koulutusmenot (tai oikealla termillä koulutuskulut) olivat siten hyvin pienet kaikissa ryhmissä. Sitä todistaa myös se, että kaikkien yritysten osalta koulutusmenojen mediaani oli nolla euroa. Toisaalta tässäkin kohdassa kuten edellä T\&K- menojen osalta menot olivat suurimmat tuoteinnovaatio-ryhmässä, toiseksi suurimmat тии innovaatio-ryhmässä ja alimmat perinteinen konsepti- ryhmässä antaen siten "maalaisjärjen" validiteetin käytetylle ryhmittelylle. Ryhmät eivät poikenneet myöskään yrittäjän ammatillisen eli pohjakoulutuksen osalta toisistaan. Yleisin yrittäjän koulutus oli kansa-, keski- tai peruskoulu. Tätä taustaa vasten voi todeta, että sopivaa ja "itsensä maksavaa" koulutusta joko ei ole tarjolla tai sitten sitä ei osata markkinoida kohdeyrityksille.

Tutkimuksessa mukana olleista yrittäjistä patenttia oli hakenut ja saanut kaksi yrittäjää, 9 yrittäjää oli harkinnut patentin hakemista. Patenttihakemusten määrää ei voida pitää maatilakytkentäisten yritysten innovatiivisuuden mittarina, vaikka yritysryhmien välillä oli tilastollisesti merkitsevä ero (Kruskal-Wallis -testin p-arvo 0,007). Patentit ovat keksintöjä, jotka eivät läheskään aina päädy kaupallistettavaksi innovaatioksi. Patentin saaneet yritykset sijoittuivat tutkimuksessa tuoteinnovaatioryhmään.

Investointisuunnitelmien perustaksi laaditut liiketoimintasuunnitelmat pitivät keskimäärin verraten hyvin paikkansa. Kaikki ryhmät aliarvioivat toteutuneeseen verrattuna käyttöpääoman tarpeen, oman rahoituksen osuuden ja oman työpanoksen määrän. Molemmat innovaatioryhmät aliarvioivat myös investointikustannukset. Myyntitulot osattiin arvioida oikein innovaatioryhmissä, mutta sen sijaan perinteinen konsepti-ryhmä yliarvioi myyntitulonsa.

Maatilakytkentäisten yritysten liiketoimintakonseptien kivijalkana olivat luovat, rohkeat, tyynen rauhalliset yrittäjäjohtajat; ts. pienen yrityksen strateginen resurssi on yrittäjä itse. Menestymisen 
perustana on ennen muuta oma tieto ja osaaminen. Yrittäjät olivat luoneet yrityksistänsä "oman itsensä" näköiset. Yrittäjien katse oli suunnattuna eteenpäin uusia asioita ja haasteita miettien, kuten varsinkin tehdyistä haastatteluista ilmeni. Lisäksi tärkeänä strategisena resurssina mainittiin haastatteluissa maatilan omaisuusvaranto.

Haastateltujen sarjayrittäjien toimialoina olivat konekauppa, pesupalvelu ja maaseutumatkailu. Sarjayrittäjien oman alan ydinosaaminen oli muodostunut kokemuksen kautta. Yrittäjät olivat hyödyntäneet maatilan omaisuuserät täysimääräisesti uutta yritystoimintaa aloittaessaan. Vaikka maatalouden harjoittamisesta oli myöhemmin luovuttu, oli maatilakytkentäisyys yhä edelleen osa yrityksen henkeä. Yritysten markkina-alueet olivat laajentuneet koko Suomen alueelle. Sarjayrittäjien toiminnassa kuvastui tärkeänä osana asiakkaan tarpeiden ymmärtäminen. Palveluja kehitettiin asiakkaan toiveiden ja asiakkaan näkemien arvojen pohjalta. Yrittäjät olivat kehittäneet ympärilleen tarvitsemansa arvoverkoston. Yritysten välistä yhteistyötä tehtiin muun muassa markkinoinnissa. Yrittäjät hyödynsivät tietotekniikkaa laskutuksessa, muussa taloushallinnassa ja markkinoinnissa. Kahdella yrittäjällä oli Internet-kotisivut.

Haastateltujen portfolioyrittäjien toimialoina olivat puutuotteiden valmistus, metallituotteiden valmistus ja elintarvikkeiden jatkojalostus. Kaikkien yrittäjien ydinosaamisen muodostumisessa korostui vahva tuotekehitykseen panostaminen. Ydinosaaminen oli syntynyt koulutuksen, tiedon keräämisen ja kokeilujen kautta. Tuotekehityksessä oli myös käytetty asiantuntija-apua. Maatalouden harjoittamista oli jatkettu yritystoiminnan rinnalla. Maatalouden harjoittamisen nähtiin tukevan uuden yritystoiminnan harjoittamista antaen tietynlaista turvaa yritystoiminnan riskin varalle. Tuotteiden laatu nähtiin tärkeimmäksi tekijäksi markkinoilla menestymiseen. Asiakkaiden mielipiteitä ja näkemyksiä käytettiin hyväksi tuotteiden jatkokehittelyssä. Kaikilla portfolioyrittäjillä oli muodostunut tärkeä yhteistyötiimi omista perheenjäsenistä ja/tai työntekijöistä. Yrittäjät hyödynsivät tietotekniikkaa laskutuksessa, taloushallinnossa, markkinoinnissa ja tuotteiden suunnittelussa. Kahdella yrittäjällä oli Internet-kotisivut.

Haastateltujen asiantuntijoiden mielestä maatilakytkentäisen yritystoiminnan innovaatiojärjestelmän ja innovaatioympäristön määrittely oli vielä aika vaikeaa. Selvää, valmista mallia ei kukaan haastatelluista asiantuntijoita kyennyt esittämään. Maatilakytkentäisen yritystoiminnan merkitys nähtiin kuitenkin aina vain tärkeämmäksi maaseudun taloudellisen hyvinvoinnin muodostajana perinteisen maatalouden rakennekehityksen nopeutuessa. Verkostoitumisen merkitys maatilakytkentäisten yritysten osalta nähtiin tärkeäksi, koska yritykset ovat tyypillisesti yhden hengen yrityksiä. Idean kehittämiseen innovaatioksi koettiin tarvittavan yleensä vähintäänkin keskustelukumppani, mutta usein myös laaja asiantuntijajoukko.

Kyselytutkimuksen kohdeyritykset arvioivat innovaatiojärjestelmän toimijoiden hyvyyttä omalta kannaltaan kouluarvosanoja käyttämällä. Innovaatioympäristöön liittyvistä toimijoista parhaat kouluarvosanat saivat yrittäjiltä TE- keskus ja konsultit (n. 8.5). Huonoimmat arviot saivat MAKES, oman alan oppilaitokset ja kunnan/kaupungin viranomaiset (n. 7). Muut toimijat kuten rahoituslaitokset, ProAgria, Metsäkeskus ja oman alan hankevetäjät kuuluivat keskikastiin. Innovaatioympäristölle asetetaan paljon haasteita ja siihen sijoitetaan verraten paljon yhteiskunnan resursseja. Kasvun aikaansaamiseksi maatilakytkentäisiin yrityksiin näiden resurssien käytön tehostamiseen ja kohdentamiseen on varmasti tarvetta tämän tutkimuksen tulosten valossa

\section{Johtopäätökset}

Innovaatioiden luomisessa maatilakytkentäisissä yrityksissä tärkeintä on ollut yrittäjän omat ideat, tieto, osaaminen ja rohkeus idean kehittelyssä innovaatioksi ja liiketoiminnalliseksi sovellukseksi. Yritysostoja uusien liiketoimintakonseptien kehittämiseksi ei havaittu. Menestyvän innovaation tuottaminen markkinoille edellyttää lisäksi, että toimintapuitteet ovat kunnossa ja innovaation tuottaminen markkinoille tapahtuu ajallisesti oikeaan aikaan. Mahdollisuusikkunan täytyy olla auki. Uudesta tuotteesta yrittäjä saa hetkellisen monopolihyödyn, mutta kilpailijat seuraavat pian perästä ja murtavat verraten nopeasti tämän edun. Siksi yritysten pitäisi pystyä uudistamaan tuotteitansa jatkuvasti. Palveluinnovaatiot ovat myös keskeisiä kasvun kannalta. Palveluja uudistamalla ja monipuolistamalla saadaan liiketoiminnan piiriin yhä uusia asiakasryhmiä ja näin innovaatioiden tulo markkinoille lisää muidenkin toimijoiden kuin palveluinnovaation tekijän hyötyä. Tätä ilmiötä kutsutaan ulkoisvaikutukseksi: yrittäjän lisäksi muutkin arvoverkon ja alueen yritykset hyötyvät. 
Julkisten varojen kohdentaminen yritysten tukemisessa on jatkossa entistäkin tärkeämpää. Pienyritystoiminnan rahoitustuen jatkuvuus on pystyttävä turvaamaan, sillä rahoitustuen merkitys uusien innovaatioiden ja elinkeinojen kehittymiselle maaseudulla on tärkeää. Kehittämishankkeista tulisi pystyä saamaan laajempien kokonaisuuksien alla entistä paremmin toimialakohtaisiin erityiskysymyksiin paneutuvia ongelmanratkaisuhankkeita, niin että ne voisivat vastata kehittyvien yritysten tarpeisiin.

Entistä paremman innovaatiokulttuurin aikaansaamiseksi yrityksissä ja julkisissa organisaatioissa tulisi kannustaa yksilöiden luovuutta, rohkeutta ja riskinottokykyä. Innovaatioympäristön kehittämisen haasteena on luoda instrumentteja, joilla yritysten vuorovaikutusta ja liiketoimintaosaamista voitaisiin kehittää. Yksi yksilöity haaste voitaisiin esittää kaikille mainituille toimijoille. Kehittämiskoulutuksessa olisi mentävä aimo askel täsmäkoulutuksen suuntaan. Nykyinen kehittämiskoulutus ei kohtaa maaseutukytkentäisten yritysten tarpeita.

\section{Kirjallisuus}

Aghion, P. \& Howitt, P. 1992. A Model of Growth through Creative Destruction. Econometrica, Vol.60. No.2:323 -351.

Hautamäki, A. \& Kuusi, J. 2005. Suomi innovaatiotoiminnan kärkimaaksi. Kilpailukykyinen innovaatioympäristö -kehittämisohjelman loppuraportti. Sitra. $35 \mathrm{~s}$. Helsinki.

Hamel, G. 2001. Vallankumouksen kärjessä. 328 s. Porvoo.

Kujala, P. 2005. Innovatiivisten liiketoimintakonseptien merkitys maatilakytkentäisten yritysten kehittämisen ja kasvun mahdollistajana. Maatalouden liiketaloustieteen pro-gradu-tutkielman käsikirjoitus. $76 \mathrm{s.}+$ liitteet.

Lehtonen, P. Liiketoimintaosaaminen sekä Tapayrittäjyys. Saatavilla: http://cie.hkkk.fi/25c240.

Romer, P.M. 1990. Endogenous Technological Change. Journal of Political Economy. 98 (5): 71-102. Romer, P.M. 1994. The Origins of Endogenous Growth. The Journal of Economic Perspectives, vol. 8. No.1: 3-22.

Tekes 2003. Alueiden elinvoima syntyy innovaatioista. Osaaminen, erikoistuminen ja verkottuminen ratkaisevat menestyksen kansainvälisessä kilpailussa. $31 \mathrm{~s}$. Helsinki.

Tike 2004. Maa - ja metsätalousministeriön tietopalvelukeskus. Maatilojen muu yritystoiminta. Maatalouden rakennetutkimus 2003. 33 s. Helsinki. 